\title{
The relationship between anomie and participation of Latvian inhabitants in social activities
}

\author{
J. Levina ${ }^{1}$, K. Martinsone ${ }^{1}$, and D. Kamerade ${ }^{2}$ \\ ${ }^{1}$ Rīga Stradiņš University, Riga, Latvia \\ ${ }^{2}$ University of Birmingham, Birmingham, UK
}

\begin{abstract}
The purpose of this research was to investigate relations between different dimensions of anomie of Latvian inhabitants and their participation in social activities, as well as to find what social activities of Latvian inhabitants best predict their sense of anomie. In this research the secondary data from the third European Quality of Life Survey (European Quality of Life Survey (EQLS), 2012) was used. The Latvian sample consisted of respondents $(n=1009)$, aged from 18 to 92 years (male $-34.9 \%$, female $65.1 \%$ ). To assess anomie three subscales of anomie - Social distrust, Social isolation and Meaninglessness - were used. These subscales [1-5] were constructed basing on the integrative multidimensional model of anomie, developed by L̦evina, Mārtinsone and Kamerāde [1-6], and using questions from the third European Quality of Life Survey [7]. To measure social activities, twenty questions of the third European Quality of Life Survey were used. It was found that all three aspects of anomie - social distrust, social isolation and meaninglessness - were negatively associated with such social activities as interaction with others without doing a specific activity with them, doing an activity with others, helping others and contributing to society (civic activities). Contact by phone, the Internet or by post with a brother, sister or other relative best of all predicted social distrust. Contact by phone, the Internet or by post with any of friends or neighbours, as well as with a brother, sister or other relative together with participation in social activities in a club, society, or an association and attending a meeting of a trade union, a political party or political action group best of all predicted social isolation. Meaninglessness best of all could be predicted by contact by phone, the Internet or by post with any of friends or neighbours as well as with brother, sister or other relative and by being a volunteer and doing unpaid voluntary work through education, cultural, sports or professional associations.
\end{abstract}

\section{Introduction}

Socially economic changes can cause anomie at the level of society and anomie at the individual level. Anomie is defined as a state of society characterized by lack of norms and regulations, i.e., a state in which there is a breakdown of social norms and guidance for the citizens of a society [8], as well as a discrepancy between common social goals and the legitimate means to attain those goals [9]. Anomie is an individually psychological state when the person believes that there are no social norms, rules and regulations, which can regulate their own behavior as well as the behavior of other citizens of the society, when the person endures the psychological state of meaninglessness and social isolation $[3,5,10]$. 
While anomie is one of the important factors of society well-being, its consequences affect individual life of members of society. At the individual level anomie influences the psychological health and well-being of individuals. Specifically, there is empirical evidence showing that anomie is negatively associated with such components of subjective wellbeing as overall life satisfaction and satisfaction with different life domains as well as with general sense of happiness [10]. Higher feeling of anomie is connected with higher suicidal tendencies [11, 12]. Anomie is associated with substance use: substance users showed significantly higher anomie scores than nonusers on alcohol, tobacco, marijuana, LSD, amphetamines, and barbiturates [13]. Anomic individuals have low self-esteem [14]. On the base of the analysis of literature [6], it was concluded that the dimensions of anomie were connected to a sense of security, specifically, that anomie could cause such a psychological consequence as the loss of a sense of security, which traditionally is acknowledged as one of the basic human needs [15-17].

In light of these findings, research on anomie can be recognized as one of the topical themes in the field of psychology. Research of anomie is especially topical in modern conditions when the society endures rapid social and economic changes, such as the global economic crisis of 2008 and the recovery after it, changes in the labour market, contemporary migration processes, modern crises of political systems in various countries, contemporary ethnic conflicts and others. Within the last two decades also Latvian society endured certain social and economic transitions, which could cause anomie.

Therefore, research of factors, which can reduce the negative impact of these changes and decrease the level of anomie, is topical worldwide, as well as in Latvia.

Social participation is recognized as one of key determinants of successful and healthy functioning of society and human functioning $[18,19]$. As the present study is focused on anomie, in this paper we explore if participation in social activities can serve as a factor, which reduces negative impacts of social transformations decreasing anomie at the individual level in Latvian population.

Thus, the main purpose of this research is to investigate relations between anomie and participation of Latvian inhabitants in social activities.

\section{The concept of anomie and factors influencing it}

\section{The notion and structure of anomie}

In our recent studies $[3,5,10]$, as it was previously mentioned, anomie was conceptualized as an individual psychological state when the person believes that there are no social norms, rules and regulations, which can regulate their own behaviour as well as the behaviour of other citizens of the society, when the person endures the psychological state of meaninglessness and social isolation. Thus, anomie is considered as multidimensional. According to this view a new integrative multidimensional model of anomie was developed [1-6].

Initially we proposed that anomie had three dimensions - lack of norms, social isolation and meaninglessness [2].

Subsequently, each major dimension of anomie was divided into two sub-dimensions [4]. Lack of norms was divided into an individual's deviation from prescribed rules or customs and social distrust, social isolation - into estrangement to others and cultural isolation, and meaninglessness - into the lack of goal clarity and generalized sense of meaninglessness.

Finally, after the revision of this integrative model of anomie we defined also main signs of anomie $[1,3,5,6]$. In accordance with the revised version of the integrative multidimensional model of anomie, the lack of an individual's respect of presumed norms and readiness to engage in particular acts of deviance and to use non-normative means are 
main signs of an individual's deviation from prescribed rules or customs, while the lack of trustworthiness to government and other social institutions as well as to other people are signs of social distrust. The lack of social support, the sense of loneliness, the sense of alienation, the sense of social inferiority are the main signs of estrangement to others, when the sense of loss of internalized social norms and values is the main sign of cultural isolation. Finally, the main sign of the lack of goal clarity is being without desirable and sensible goals, while the main signs of the generalized sense of meaninglessness are the sense of lack of control and freedom, the sense of boredom, pessimism about the future.

\section{The genesis of anomie and factors influencing it}

One of the main issues is which factors influence anomie, cause this individual psychological state and allow predicting of it, facilitate anomic feelings, as well as what are possibilities of the decline of anomie. The research in this field is especially topical in the conditions of social transformations, society reorganization, changes in economic life.

A possible mechanism underlying the genesis of anomie is found in Durkheim's theory of anomie and anomic suicide [8,20] as well as in more contemporary studies based on the works of Durkheim.

According to this approach, at the level of society, anomie which can be described as society's decreasing capacity for individual integration (aims) and regulation (means), occurs because of macro-social change if traditional norms vanish in the course of social change but are not replaced by new ones [21]. In its turn, the macro level (social structure) affects micro level (behaviours and attitudes of individuals).

On the one hand, high integration of the society fosters strong social bonds and common social values. A strongly integrated society is characterized by keeping the individual under its control, as well as by constant exchange of feelings and ideas, and fills its members with religious, political and moral beliefs that control their actions [20]. As Thorlindsson and Bjarnason note, "the extent, to which society regulates an individual, will determine his or her meaning of life" [22, p. 98].

On the other hand, if the integration of the society declines and if social regulations diminish and the society does not have any influence on the regulations of individual's behaviour, people get disoriented and develop feelings of insecurity and deprivation [21]. The person finds himself/herself in a contradictory world where no regulations determine his/her desires and aspirations, and faces frustration and disappointment [12]. Lack of society integration and regulations results in the collapse of social and moral norms within the society that, in its turn, makes individuals anomic, when they feel isolation from society, despair, alienation from social institutions, and feeling of powerlessness [12].

The literature analysis allows us to conclude that there are also some studies on the factors facilitating anomic feelings. Thus, in the research of socio-demographic groups which could be more vulnerable to socio-economic changes and could demonstrate the highest levels of anomie it was found that there were age differences in levels of anomie [5]. In particular, it was found that, firstly, middle-aged adults had higher scores for social isolation than respondents from the group of early adults, and, secondly, that late adolescents-youths had the lowest scores for meaninglessness comparing with all other age groups, and early adults - lower scores for meaninglessness than middle and late adults. It was concluded that certain socio-demographic groups reported the elevated level of anomie because they could have less possibilities for social inclusion and participation offered by the society [5].

One of the important factors facilitating anomic feelings of an individual is his or her family experience [23]. Specifically, it is concluded that anomic depression as a reaction to 
a sense of perceived meaninglessness often occurs in times of cultural confusion and sociocultural disintegration and in periods of rapid changes, which disrupt a family's ability to discover a sense of meaning and purpose in life. In particular, anomic depression as a sense of emptiness and as an inability to continue to experience life as meaningful can occur when a family migrates to a new geographical area and when there is an increased danger of a disruption in the family's traditional methods of discovering and experiencing meaning [23]. This fact makes us suppose that providing opportunities for participation in social activities help such family to become more integrated into a new socio-cultural environment as well as to discover new significant purposes in life.

Summarizing the results of the literature analysis it is possible to conclude that, rapid social, economic, political, cultural changes can lead to anomie - a social state in which the integration of the society declines and regulations diminish. In its turn, the decline of the integration of the society and the collapse of the system of social regulation cause anomie, when a person faces perceived lack of norms, feels social isolation and meaninglessness. Moreover, certain socio-demographic groups can report the elevated level of anomie because they can have little possibilities for social inclusion and participation offered by the society.

In the light of these theoretical assumptions, it is possible to propose that participation in social activities which are performed in interaction with others, especially in those, which are oriented toward helping others or contribute more broadly to society, can help people to decline anomic feelings and to find significant meanings of life, restore social trust and the sense of social inclusion.

\section{Participation in social activities and its relationship with anomie}

Doing things for people and helping others can create a better community environment at the level of society and can serve as a source of good feelings, satisfaction, a sense of personal fulfillment and self-confidence at the individual level [19].

In his review of research on the consequences of such social activity as volunteering Wilson [18] demonstrated beneficial effects of this form of social participation in four areas: citizenship, antisocial behavior, physical and mental health, and socioeconomic achievement.

Regardless the great importance of participation in social activities to physical and mental health of an individual and to his/ her social functioning, as well as to the successful functioning of society in general, there is no agreement on its definition. Researchers point out the diversity of definitions of social participation, the lack of consensus around a definition of social participation, as well as the existence of many similar concepts. However, recently Levasseur and co-authors [24] provided an inventory and content analysis of definitions of social participation. Based on the results of the conducted content analysis of definitions, the authors concluded that social participation definitions mostly focused on the person's involvement in activities providing interactions with others in society or the community.

Since, according to Levasseur and co-authors, social activities proved to be the most frequent, significant and analyzable dimension found in the definitions of social participation, the activity analysis was performed to classify social activities. Depending on the individual proximity of involvement with others and the main goal of these social activities, taxonomy of social activities was proposed - six levels of involvement of an individual with others were identified:

- level 1 - doing an activity in preparation for connecting with others;

- level 2 - being with others; 
- level 3 - interacting with others without doing a specific activity with them;

- level 4 - doing an activity with others;

- level 5 - helping others;

- level 6 - contributing to the society.

Concerning the individual proximity of involvement with others, social activities of the first level of the taxonomy, can be described as performed alone, social activities of the second level - as performed in parallel, while social activities of the third, fourth, fifth and sixth levels - as performed in interaction with others.

Regarding the main goal, social activities can be categorized as follows: basic need oriented activities (the first and second levels of the taxonomy), socially oriented (the third level), task oriented (the fourth level), oriented toward helping others (the fifth level), and society oriented (the sixth level).

Finally, social activities were classified into three categories: activities performed for oneself (the first and second levels), activities performed with others (the third and fourth level), and activities performed for others (the fifth and sixth levels).

As the decline of the integration of the society and the collapse of the system of social regulation cause anomie, when a person faces perceived lack of norms, feels social isolation and meaninglessness, participation in those forms of social activities which are performed in interaction with others, is more likely to reduce anomic feelings.

\section{The present study}

Examination of the existing literature allows us to conclude that social, economic, political, and cultural changes can cause anomie at the level of society and anomie at the individual level. Anomie is experienced as perceived lack of norms, which includes an individual's deviation from prescribed rules or customs and social distrust, as social isolation, specifically, as estrangement to others and cultural isolation, and as meaninglessness, i.e., as the lack of goal clarity and generalized sense of meaninglessness.

Analysis of the literature allows us to conclude that in times of social transformations, society reorganization, changes in economic, political, cultural life participation in social activities are likely to serve as a factor reducing anomie or helping to recovery from such an experience.

As Latvian society during the last two decades endured certain social and economic transitions, which could cause anomie, the main objective of this study is to investigate relations between anomie and participation of Latvian inhabitants in social activities.

In the current study we hypothesized that participation in social activities, which are performed in interaction with others, are negatively associated with anomie.

We also formulate the following additional research question - what social activities best predict levels of anomie of Latvian inhabitants?

\section{Materials and methods}

In order to investigate relations between anomie and participation of Latvian inhabitants in social activities the questions of the interview and secondary data from the third European Quality of Life Survey were used. The European Quality of Life Survey examines the objective circumstances of European citizens' lives and how they feel about those circumstances and their lives in general. 


\section{Participants}

The sample consisted of the inhabitants of Latvia $(n=1009)$, aged from 18 to 92 years (male - 34.9\%, female - 65.1\%) who took part in the third European Quality of Life Survey [7].

The Latvian sample was obtained by random sampling. Thus, the Latvian sample can be viewed as nationally representative.

\section{Instruments}

Anomie. To measure the levels of anomie of Latvian inhabitants Anomie Scale was used. This Anomie Scale was developed by Ļevina, Mārtinsone and Kamerāde [1-5] using questions and secondary data from the European Quality of Life Survey [7].

Anomie Scale measures three dimensions of anomie - social distrust as a component of the lack of norms, social isolation and meaninglessness. All three subscales showed acceptable or good internal consistency. Cronbach's alpha coefficients for all subscales ranged from .69 to .84 .

Social activities. To measure the social activities of Latvian inhabitants twenty questions from the third European Quality of Life Survey [7] were used. These twenty questions were selected on the base of the taxonomy of social activities proposed by Levasseur, Richard, Gauvin and Raymond [24].

At the first stage from all original questions of the third European Quality of Life Survey an initial pool of questions referring to participation in different social activities was selected.

At the second stage the questions from this selected initial pool were compared with the levels of the taxonomy of social activities. Finally, in this research only those questions were chosen which referred to those types of social activities which were performed in interaction, "with others" or "for others", i.e, to social activities of the 3-6th levels of the proposed taxonomy (see Table 1).

Eight selected questions measure interacting with others - without doing a specific activity with them/ doing an activity with others (with relatives, friends or neighbors) - through the direct face-to-face contact (Q33a-Q33d) or through the contact by phone, the Internet or by post (Q34a-Q34d).

One question (Q21d) measures collaborating with others and reaching a common goal (doing a specific activity with others). Two questions (Q36a and Q36c) refer to helping others as a caregiver and five questions (Q22a-Q22e) - as a volunteer. Finally, four selected questions (Q23a-Q23d) are about civic activities, i.e., refer to contributing to society.

Original responses to Q33a, Q33b, Q33c, Q34a, Q34b and Q34c are made on a 5-point scale ( 1 - every day or almost every day; 2 - at least once a week; 3 - one to three times a month; 4 - less often; 5 - never) with additional response 6 - do not have such relatives. The values of the respondent's response were reversed as follows: 1 - never/ do not have such relatives; 2 - less often; 3 - one to three times a month; 4 - at least once a week; 5 - every day or almost every day. The higher score means the more frequent participation in a certain social activity.

Original responses to Q33d and to Q34d as well as to Q21d are made on a 5-point scale ( 1 - every day or almost every day; 2 - at least once a week; 3 - one to three times a month; 4 - less often; 5 - never). Also the values of the respondent's response were reversed as follows: 1 - never; 2 - less often; 3 - one to three times a month; 4 - at least once a week; 5 - every day or almost every day. The higher score means the more frequent participation in a certain social activity.

Original responses to Q36a and to Q36c are made on a 5-point scale (1 - every day; 2 - several days a week; 3 - once or twice a week; 4 - less often; 5 - never). The values of 
Table 1. Questions selected from the third European Quality of Life Survey $(E Q L S, 2012)$ and different types of social activities based on the taxonomy of social activities proposed by Levasseur, Richard, Gauvin and Raymond (Levasseur, Richard, Gauvin, \& Raymond, 2013).

Questions from the EQLS

Characteristics of social activities

\section{Level of involvement of the Goals of the activity individual with others}

Interacting with others without doing a specific activity with them/ doing an activity with others

\begin{tabular}{|c|c|c|}
\hline \multicolumn{3}{|c|}{ Q33 On average, thinking of people living outside your } \\
\hline \multicolumn{3}{|c|}{$\begin{array}{l}\text { household how often do you have direct face-to-face contact } \\
\text { with...? }\end{array}$} \\
\hline Q33a Any of your children? & Level 3/ level 4 (in interaction) & Socially oriented/ task oriented \\
\hline Q33b Your mother or father? & Level 3/ level 4 (in interaction) & Socially oriented/ task oriented \\
\hline Q33c Any brother, sister or other relative? & Level 3/ level 4 (in interaction) & Socially oriented/ task oriented \\
\hline Q33d Any of your friends or neighbors? & Level 3/ level 4 (in interaction) & Socially oriented/ task oriented \\
\hline \multicolumn{3}{|c|}{ Q34 And on average, how often do you have contact with } \\
\hline \multicolumn{3}{|c|}{ friends or family living outside your household by phone, the } \\
\hline \multicolumn{3}{|l|}{ Internet or by post? } \\
\hline Q34a With any of your children? & Level 3/ level 4 (in interaction) & Socially oriented/ task oriented \\
\hline Q34b With your mother or father? & Level 3/ level 4 (in interaction) & Socially oriented/ task oriented \\
\hline Q34c With any brother, sister or other relative? & Level 3/ level 4 (in interaction) & Socially oriented/ task oriented \\
\hline Q34d With any of your friends or neighbors? & Level 3/ level 4 (in interaction) & Socially oriented/ task oriented \\
\hline
\end{tabular}

Doing an activity with others

Q21d How frequently do you participate in social activities of a

Level 4 (in iteraction)

Task oriented

club, society, or an association?

Helping others - Being a caregiver

Q36 In general, how often are you involved in any of the following activities outside of work?

Q36a Caring for your children, grandchildren? $\quad$ Level 5 (in interaction) Oriented toward helping others Q36c Caring for elderly or disabled relatives? Level 5 (in interaction) Oriented toward helping others

Helping others - Being a volunteer

Q22 How often did you do unpaid voluntary work through the following organisations in the last 12 months:

Q22a Community and social services?

Q22b Education, cultural, sports or professional associations?

Q22c Social movements or charities?

Q22d Political parties, trade unions?

Q22e Other voluntary organisations?
Level 5 (in interaction) Level 5 (in interaction) Level 5 (in interaction) Level 5 (in interaction) Level 5 (in interaction)
Oriented toward helping others Oriented toward helping others Oriented toward helping others Oriented toward helping others Oriented toward helping others

Contributing to society (civic activities)

Q23 Over the last 12 months, have you ...?

Q23 a Attended a meeting of a trade union, a political party or political action group?

Q23b Attended a protest or demonstration?

Q23c Signed a petition, including an e-mail or on-line petition?

Q23d Contacted a politician or public official?

Level 6 (in interaction)

Level 6 (in interaction)

Level 6 (in interaction)

Level 6 (in interaction)
Society oriented

Society oriented

Society oriented

Society oriented

the respondent's response to these two questions were reversed as follows: 1 - never; 2 - less often; 3 - once or twice a week; 4 - several days a week; 5 - every day). The reason was the same as in the previous questions - the higher score means the more frequent participation in a certain social activity.

Original responses to Q22a-Q22e are made on a 4-point scale (1 - every week; 2 - every month; 3 - less often/ occasionally; 4 - not at all). The values of the respondent's response to 


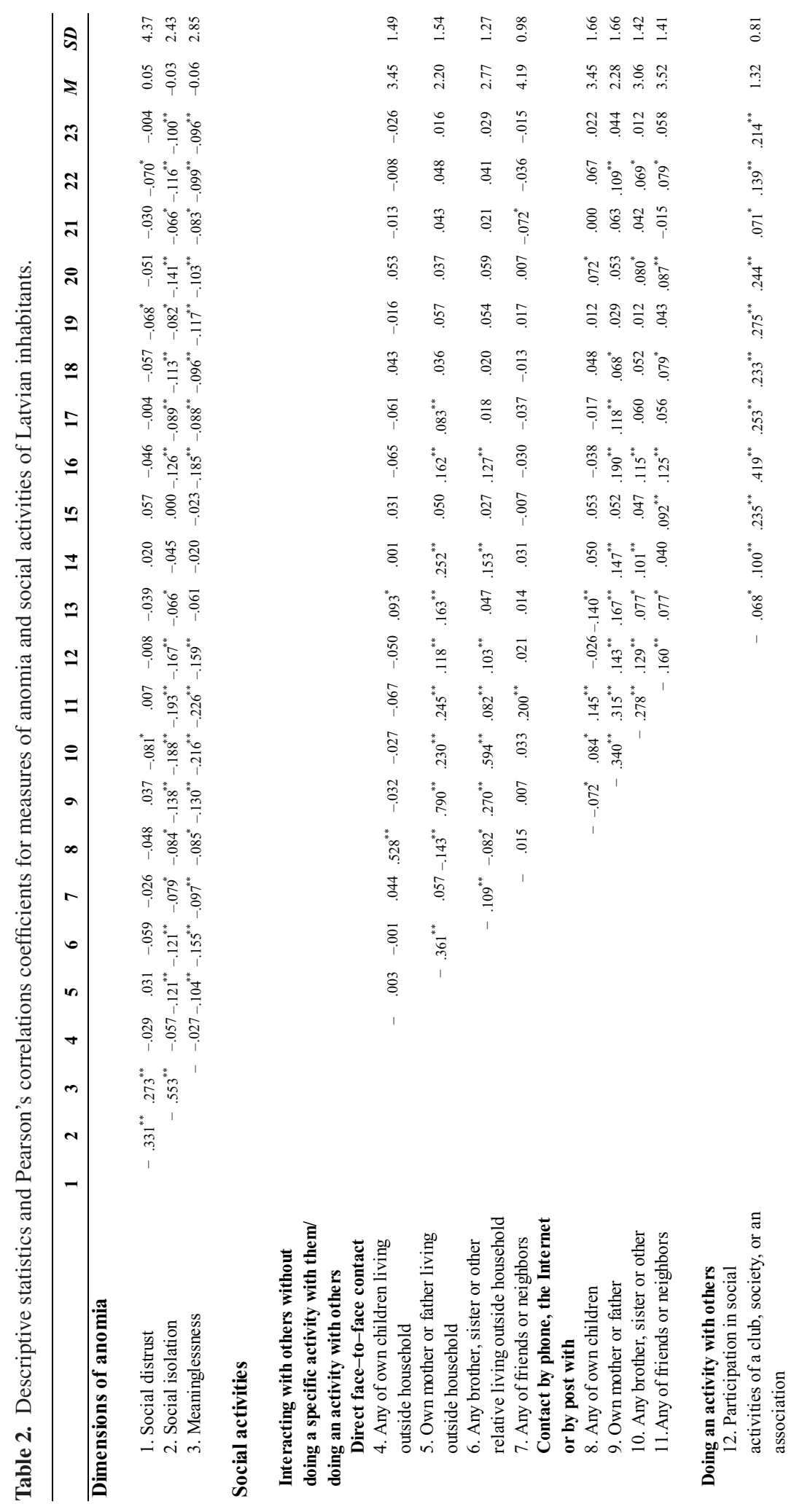




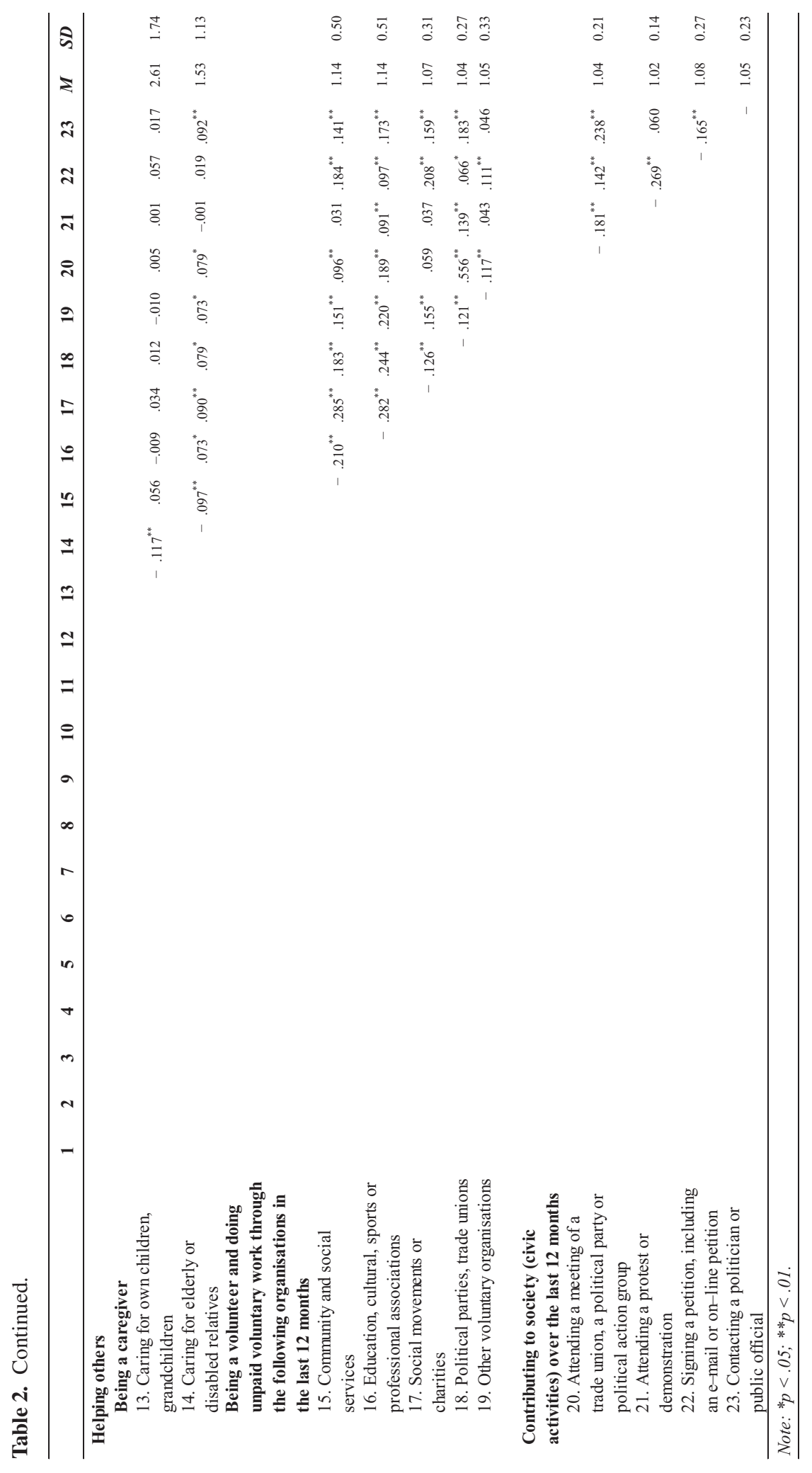


these questions were reversed as follows: 1 - not at all; 2 - less often/ occasionally; 3 - every month; 4 - every week.

Original responses to Q23a-Q23d are made on a 2-point scale (1 - yes; 2 - no) and the values of the respondent's response to these two questions were reversed as follows: $1-$ no; $2-$ yes.

Thus, all the original responses to the selected questions of the EQLS were reversed - the higher score means the more frequent participation in a certain social activity.

\section{Procedure}

As already mentioned, in order to investigate relations between anomie and participation of Latvian inhabitants in social activities the secondary data from the third European Quality of Life Survey [7] was used.

The European Quality of Life Survey is carried out every four years. The fieldwork (data collection) of the third EQLS survey in Latvia started in September 2011 and lasted till December of 2011. In this research the secondary data analysis was performed in July 2015.

\section{Results}

\section{Results of the research of relations between dimensions of anomie and social activities of Latvian inhabitants}

As it was previously mentioned, in this research it is expected that participation in social activities, which are performed in interaction with others, are negatively associated with anomie. Thus the main aim of the research was to investigate if participation of Latvian inhabitants in social activities, which are performed in interaction with others, is negatively associated with different dimensions of anomie.

To clarify the relations between different dimensions of anomie of Latvian inhabitants (i.e., social distrust, social isolation and meaninglessness) and their participation in social activities the Pearson's correlation analysis was used (Table 2).

Firstly, it was found that such dimension of anomie as social distrust was negatively associated with such social activities as (1) contact by phone, the Internet or by post with any brother, sister or other relative $(p<.05)$, (2) being a volunteer and doing unpaid voluntary work through a voluntary organisation $(p<.05)$ and $(3)$ signing a petition, including an e-mail or on-line petition $(p<.05)$.

Secondly, it was found that social isolation was negatively associated with such social activities as (1) direct face-to-face contact with own mother or father living outside household $(p<.01)$, a brother, sister or other relative living outside household $(p<.01)$, any of friends or neighbors $(p<.05),(2)$ contact by phone, the Internet or by post with any of own children $(p<.05)$, with own mother or father $(p<.01)$, a brother, sister or other relative $(p<.01)$, any of friends or neighbors $(p<.01)$, (3) participation in social activities of a club, society, or an association $(p<.01)$, (4) caring for own children, grandchildren $(p<.05)$, (5) being a volunteer and doing unpaid voluntary work through the following organizations: education, cultural, sports or professional associations $(p<.01)$, social movements or charities $(p<.01)$, political parties, trade unions $(p<.01)$, other voluntary organisations $(p<.05)$, (6) such civic activities as attending a meeting of a trade union, a political party or political action group $(p<.01)$, attending a protest or demonstration $(p<.05)$, signing a petition, including an e-mail or on-line petition $(p<.01)$, as well as contacting a politician or public official $(p<.01)$. 
Table 3. Regression analysis summary for social activities, predicting social distrust.

\begin{tabular}{|c|c|c|c|}
\hline & $\beta$ & $R^{2}$ & $F$ \\
\hline Step 1 & & .005 & $4.571 *$ \\
\hline $\begin{array}{l}\text { Contact by phone, the Internet or by post with any brother, } \\
\text { sister or other relative }\end{array}$ & $-.074^{*}$ & & \\
\hline Step 2 & & .009 & $3.717 *$ \\
\hline $\begin{array}{l}\text { Contact by phone, the Internet or by post with any brother, } \\
\text { sister or other relative }\end{array}$ & $-.069^{*}$ & & \\
\hline Signing a petition, including an e-mail or on-line petition & -.059 & & \\
\hline Step 3 & & .012 & $3.429 *$ \\
\hline $\begin{array}{l}\text { Contact by phone, the Internet or by post with any brother, } \\
\text { sister or other relative }\end{array}$ & -.066 & & \\
\hline $\begin{array}{l}\text { Signing a petition, including an e-mail } \\
\text { or on-line petition }\end{array}$ & -.053 & & \\
\hline $\begin{array}{l}\text { Being a volunteer and doing unpaid voluntary work through } \\
\text { through voluntary organisation }\end{array}$ & -.059 & & \\
\hline
\end{tabular}

Note: $* p<.05 ; * * p<.01$.

Finally, correlation analysis showed that the third dimension of anomie - meaninglessness - was negatively associated with (1) direct face-to-face contact with own mother or father living outside household $(p<.01)$, a brother, sister or other relative living outside household $(p<.01)$, any of friends or neighbors $(p<.01)$, (2) contact by phone, the Internet or by post with any of own children $(p<.05)$, with own mother or father $(p<.01)$, a brother, sister or other relative $(p<.01)$, any of friends or neighbors $(p<.01),(3)$ participation in social activities of a club, society, or an association $(p<.01)$, (4) being a volunteer and doing unpaid voluntary work through the following organisations: education, cultural, sports or professional associations $(p<.01)$, social movements or charities $(p<.01)$, political parties, trade unions $(p<.01)$, other voluntary organisations $(p<.01)$, (5) such civic activities as attending a meeting of a trade union, a political party or political action group $(p<.01)$, attending a protest or demonstration $(p<.05)$, signing a petition, including an e-mail or on-line petition $(p<.01)$, as well as contacting a politician or public official $(p<.01)$.

\section{Results of the research of prediction of levels of anomie of Latvian inhabitants from indicators of their participation in social activities}

In order to determine participation in which social activities best predict levels of anomie of Latvian inhabitants' regression analysis was performed. Hierarchical multiple regression was performed to determine what social activities best of all predict such dimensions of anomie as social distrust, social isolation and meaninglessness.

Table 3 summarizes the results of regression analysis on social distrust as dependent variable.

The regression analysis reveals that contact by phone, the Internet or by post with a brother, sister or other relative best of all predicts social distrust. Signing a petition, including an e-mail or on-line petition in the second model does not significantly improve the prediction $\left(R^{2}\right.$ change $\left.=.003, F(1,826)=2.853, p>.05\right)$ as well as being a volunteer and doing unpaid voluntary work through voluntary organisation in the third model also does not improve the prediction $\left(R^{2}\right.$ change $\left.=.003, F(1,825)=2.837, p>.05\right)$.

Table 4 summarizes the results of regression analysis on social isolation as dependent variable. As independent variables from all social activities which were associated with social 
Table 4. Regression analysis summary for social activities, predicting social isolation.

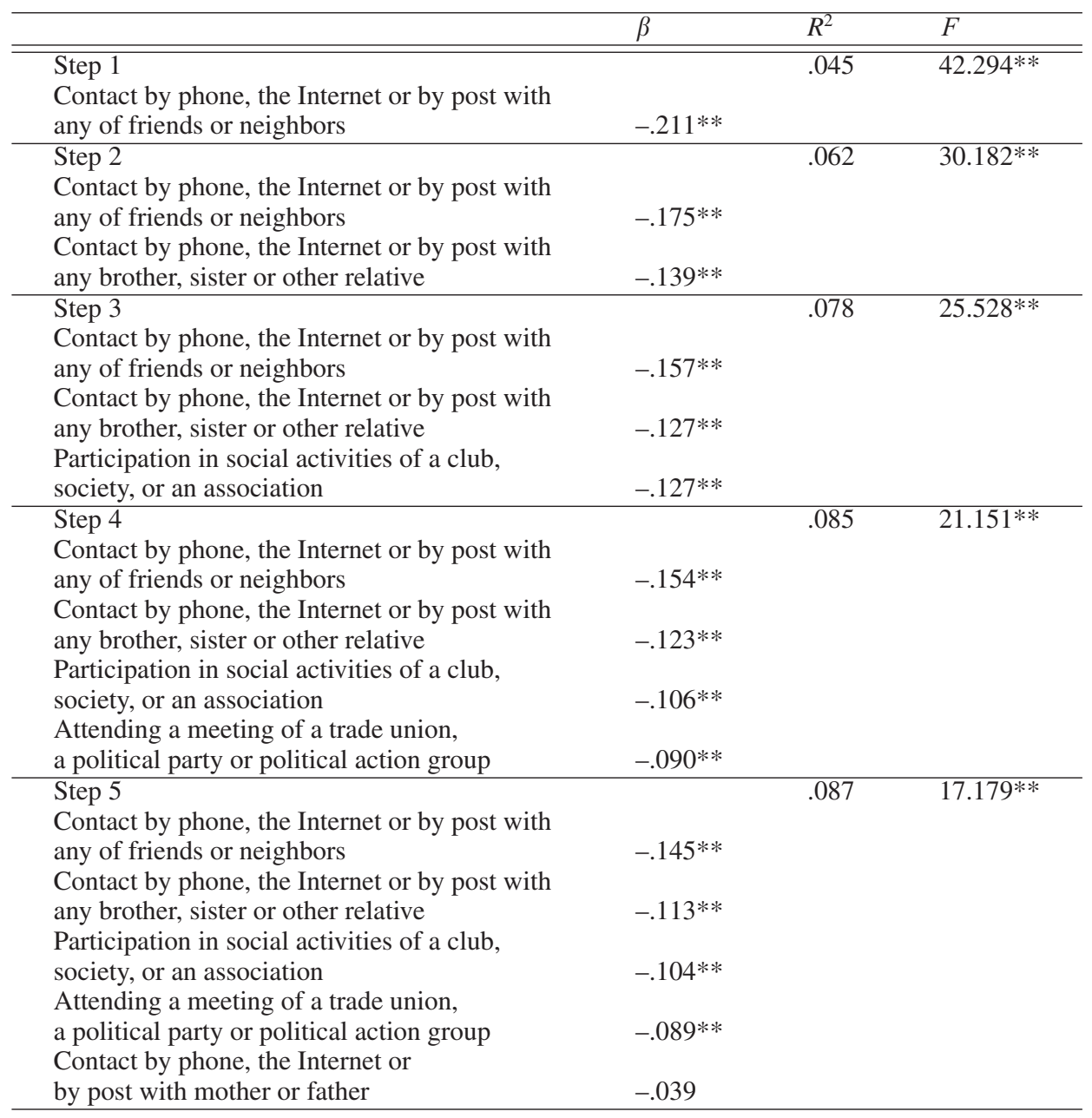

Note: $* p<.05 ; * * p<.01$.

isolation those five social activities were used, which correlated with social isolation stronger than other social activities.

Such social activity as contact by phone, the Internet or by post with any of friends or neighbors best of all predicts social isolation. Contact by phone, the Internet or by post with a brother, sister or other relative in the second model significantly improves the prediction $\left(R^{2}\right.$ change $\left.=.018, F(1,907)=17.311, p<.01\right)$. Also participation in social activities of a club, society, or an association in the third model significantly improves the prediction $\left(R^{2}\right.$ change $=.016, F(1,906)=15.269, p<.01)$ as well as attending a meeting of a trade union, a political party or political action group significantly improves the prediction in the fourth model $\left(R^{2}\right.$ change $\left.=.008, F(1,905)=7.473, p<.01\right)$. In its turn, contact by phone, the Internet or by post with mother or father in the fifth model does not significantly improve the prediction $\left(R^{2}\right.$ change $\left.=.001, F(1,904)=1.265, p>.05\right)$.

Table 5 summarizes the results of regression analysis on meaninglessness as dependent variable. As independent variables from all social activities which were associated with 
Table 5. Regression analysis summary for social activities, predicting meaninglessness.

\begin{tabular}{|c|c|c|c|}
\hline & $\beta$ & $R^{2}$ & $F$ \\
\hline Step 1 & & .053 & $50.889 * *$ \\
\hline $\begin{array}{l}\text { Contact by phone, the Internet or by post with } \\
\text { any of friends or neighbors }\end{array}$ & $-.299 * *$ & & \\
\hline Step 2 & & .075 & $37.076^{* *}$ \\
\hline $\begin{array}{l}\text { Contact by phone, the Internet or by post with } \\
\text { any of friends or neighbors }\end{array}$ & -.188 & & \\
\hline $\begin{array}{l}\text { Contact by phone, the Internet or by post with } \\
\text { any brother, sister or other relative }\end{array}$ & $-.155^{* *}$ & & \\
\hline Step 3 & & .096 & $32.259 * *$ \\
\hline $\begin{array}{l}\text { Contact by phone, the Internet or by post with } \\
\text { any of friends or neighbors }\end{array}$ & $-.173 * *$ & & \\
\hline $\begin{array}{l}\text { Contact by phone, the Internet or by post with } \\
\text { any brother, sister or other relative }\end{array}$ & $-.142 * *$ & & \\
\hline $\begin{array}{l}\text { Being a volunteer and doing unpaid voluntary } \\
\text { work through education, cultural, sports or } \\
\text { professional associations }\end{array}$ & $-146^{* *}$ & & \\
\hline Step 4 & & .098 & $24.965 * *$ \\
\hline $\begin{array}{l}\text { Contact by phone, the Internet or by post } \\
\text { with any of friends or neighbors }\end{array}$ & $-.167 * *$ & & \\
\hline $\begin{array}{l}\text { Contact by phone, the Internet or by post } \\
\text { with any brother, sister or other relative }\end{array}$ & $-.138 * *$ & & \\
\hline $\begin{array}{l}\text { Being a volunteer and doing unpaid voluntary } \\
\text { work through education, cultural, sports or } \\
\text { professional associations }\end{array}$ & $-.122 * *$ & & \\
\hline $\begin{array}{l}\text { Participation in social activities of a club, } \\
\text { society, or an association }\end{array}$ & -.060 & & \\
\hline Step 5 & & .102 & $20.651 * *$ \\
\hline $\begin{array}{l}\text { Contact by phone, the Internet or by post } \\
\text { with any of friends or neighbors }\end{array}$ & $-.174 * *$ & & \\
\hline $\begin{array}{l}\text { Contact by phone, the Internet or by post } \\
\text { with any brother, sister or other relative }\end{array}$ & $-.095^{*}$ & & \\
\hline $\begin{array}{l}\text { Being a volunteer and doing unpaid voluntary } \\
\text { work through education, cultural, sports or } \\
\text { professional associations }\end{array}$ & $-.117 * *$ & & \\
\hline $\begin{array}{l}\text { Participation in social activities of a club, } \\
\text { society, or an association }\end{array}$ & -.058 & & \\
\hline $\begin{array}{l}\text { Direct contact face-to-face with brother, } \\
\text { sister or other relative living outside household }\end{array}$ & -.070 & & \\
\hline
\end{tabular}

meaninglessness those five social activities were used, which correlated with meaninglessness stronger than other social activities.

The regression analysis shows that such social activity as contact by phone, the Internet or by post with any of friends or neighbors best of all predicts meaninglessness. Contact by phone, the Internet or by post with any brother, sister or other relative in the second model significantly improves the prediction $\left(R^{2}\right.$ change $=.022, F(1,917)=22.093, p<$ $.01)$. Also being a volunteer and doing unpaid voluntary work through education, cultural, sports or professional associations in the third model significantly improves the prediction $\left(R^{2}\right.$ change $\left.=.021, F(1,916)=21.009, p<.01\right)$. However participation in social activities of a club, society, or an association in the fourth model does not significantly improve the prediction $\left(R^{2}\right.$ change $\left.=.003, F(1,915)=2.882, p>.05\right)$. Also Direct contact faceto-face with a brother, sister or other relative living outside household in the fifth model 
does not significantly improve the prediction $\left(R^{2}\right.$ change $=.003, F(1,914)=3.160$, $p>.05)$.

\section{Discussion}

The present study was designed to investigate the relationship between anomie and participation of Latvian inhabitants in social activities. A general issue that concerned this study was whether participation in social activities performed in interaction with others could be viewed as a factor reducing anomie. In particular, the aim of this study was to examine whether participation of Latvian inhabitants in social activities which were performed with others or for others was negatively associated with the level of anomie.

The results of the present study allow us to conclude that three aspects of anomie - social distrust, social isolation and meaninglessness - are negatively associated with participation in those social activities which are performed in interaction, "with others" or "for others".

In particular, it was found that that all three dimensions of anomie were negatively associated with such social activities as contact by phone, the Internet or by post with any brother, sister or other relative, with being a volunteer and doing unpaid voluntary work through voluntary organisation and with such kind of civic activity as signing a petition, including an e-mail or on-line petition.

Additionally in this research it was also found that two dimensions of anomie - social isolation and meaninglessness - were negatively associated with such social activities as direct face-to-face contact with such relatives living outside household as mother or father, a brother, sister or other relative, as well as with any of friends or neighbours. Social isolation and meaninglessness were also negatively associated with contact by phone, the Internet or by post with such relatives as children, mother or father, as well as with any of friends or neighbours. It was also found that these two dimensions of anomie were negatively associated with participation in social activities of a club, society, or an association, with being a volunteer and doing unpaid voluntary work through the following organisations: education, cultural, sports or professional associations, social movements or charities, political parties, trade unions, as well as with such civic activities as attending a meeting of a trade union, a political party or political action group, attending a protest or demonstration, as well as with contacting a politician or public official.

Finally, the obtained results allow us to conclude that social isolation was negatively associated with such social activity as being a caregiver and caring for own children, grandchildren.

The results of the present research show that all three dimensions of anomie are negatively associated with such social activities as interacting with others without doing a specific activity with them/ doing an activity with others, helping others and contributing to society (civic activities). These social activities refer to the $3-6^{\text {th }}$ levels of the taxonomy of social activities proposed by by Levasseur, Richard, Gauvin and Raymond [24]. These activities are performed in interaction with others.

Revealed in this research negative relations between all dimensions of anomie and social activities of the mentioned above levels of the taxonomy allow us to suggest that social interactions with others can serve as one of the important factors which can decrease the level of anomie.

Interesting seems the fact from this research that much more correlations were found between participation in social activities and such dimensions of anomie as social isolation and meaninglessness. This finding makes us think that social activities of an individual are more important for the sense of social inclusion and for the sense that life is meaningful than for the sense of social order and for the belief that there are social norms, rules and 
prescriptions, which can regulate his / her own behaviour as well as the behaviour of other citizens of the society.

The additional research question was - what social activities best predict levels of anomie of Latvian inhabitants. Firstly, in this research it was found that contact by phone, the Internet or by post with a brother, sister or other relative best of all predicted social distrust. This finding allows us to propose that in the conditions of social transformations, society reorganization, changes in economic life siblings and other relatives are those "significant others", communication and interactions with whom give an opportunity to discuss news, to share thoughts and feelings, and as a consequence to maintain a sense of social trust.

Secondly, results showed that contact by phone, the Internet or by post with any of friends or neighbours, as well as with a brother, sister or other relatives together with participation in social activities of a club, society, or an association and attending a meeting of a trade union, a political party or political action group best of all predicted social isolation. This finding has the following possible explanation: during the period when the society endures social and economic changes arising anomie at the level of society and anomie at the individual level, members of the society can endure the psychological state of social isolation, i.e., feel the sense of estrangement to others and cultural isolation. According to the integrative multidimensional model of anomie $[1,3,5,6]$ the main signs of social isolation are the lack of social support, the sense of loneliness, the sense of loss of internalized social norms and values. On the one hand, contacts with relatives and close friends serve as a source of social support and protect from the sense of loneliness and estrangement to others. On the other hand, participation in such social activities as attending a club, society or an association, a meeting of a trade union, a political party or political action group, facilitates the sense of social cohesion and cultural unity, strengthens social identity of an individual. Thus, the results obtained in this research confirm the importance of socially oriented activities (interacting with others), task oriented activities (doing an activity with others to reach a common goal) and society oriented activities (civic activities) for the sense of social inclusion.

Thirdly, it was found that meaninglessness best of all can be predicted by such social activities as contact by phone, the Internet or by post with any of friends or neighbours as well as with brother, sister or other relative and as being a volunteer and doing unpaid voluntary work through education, cultural, sports or professional associations. These results, on the one hand, demonstrate the importance of companionship and interaction with relatives and friends for finding of the meaning of life, and, on the other hand, allow us to propose that participation in such social activities contributing to society as doing voluntary work, contribute to an individual's sense of goals' clarity, control and freedom. In the conditions of socio-economic transitions, participation in social activities oriented toward helping others allow an individual to find significant life goals and meanings.

\section{Conclusions}

Overall, the present study allows us to conclude that anomie is negatively associated with participation in those social activities which are performed in interaction, "with others" or "for others".

This paper provides the evidence that participation in social activities performed in interaction "with others" and "for others" is an important factor that can decrease the sense of anomie during the period of socio-economic changes. Providing opportunities for participation in social activities can be considered as one of the possible forms of intervention useful for reducing negative effects of anomie. 
The paper was supported by the National Research Program 5.2. "Economic Transformation, Smart Growth, Governance and Legal Framework for the State and Society for Sustainable Development - a New Approach to the Creation of a Sustainable Learning Community (EKOSOC-LV)".

\section{References}

[1] Levina, J., Martinsone, K. (2015). A revised integrative hierarchical model of anomia: Towards the construction of anomia indices. The 14th European Congress of Psychology "Linking technology and psychology: feeding the mind, energy for life" (Milan, Italy 7-10 July 2015): Abstract book (p. 2250). Downloaded from http://www.ecp2015.it/wp-content/uploads/2015/07/ECP2015-Abstract-Book_upd27jul1.pdf (Accessed 31 July 2015).

[2] Levina, J., Martinsone, K., Kolesnikova, J., \& Perepjolkina, V. (2014). Possibilities of research of anomie in Latvian society. In A. Vētra, A. Vilks (Eds.) 5th International Interdisciplinary Scientific Conference "Society. Health. Welfare". 2nd Conference of Speech Therapists (R̄̄ga, November 26-28, 2014): Abstracts (p. 39). Rīga: RSU.

[3] Ļevina, J., Mārtinsone, K., \& Kamerāde, D. (2015, a). A model of anomia in the Baltic States. Submitted for publication in The Interdisciplinary Social Sciences Collection.

[4] Ļevina, J., Mārtinsone, K., \& Kamerāde, D. (2015, c). Individuālās anomijas modelii Latvijas populācijā. Rīgas Stradinga universitāte. 2015.gada zinātniskā konference: Tēzes (375.lpp.). Rīga: RSU.

[5] Ļevina, J., Mārtinsone, K., \& Kamerāde, D. (2015, d). Sex and age differences in levels of anomia of Latvian inhabitants. Sabiedrība, integrācija, izglītība. Starptautiskās zinātniskās konferences materiāli. III daļa. Rēzekne: RA izdevniecība, 567-576 lpp.

[6] Ļevina J., Mārtinsone K., Kamerāde K. (2015, b). Individuālā anomija kā sabiedrības politisko, tiesisko, ekonomisko pārmaiņu indikators: tās psihologiiskās sekas. Starptautiskā zinātniskā konference "Drošības nostiprināšanas aktuālās problēmas: politiskie, sociālie, tiesiskie aspekti” (R̄̄gā 2015. gada 23. aprīllì). Programma un tēzes. International Scientific Conference "Topical Problems of Security Reinforcement: Political, Social, Legal Aspects” (Riga, April 23, 2015): Programme and Abstracts. Riga: RSU, 94-96 pp.

[7] European Quality of Life Survey (EQLS). (2012). Downloaded from http://eurof ound . europa. eu/surveys/eqls(Accessed 20 May 2015).

[8] Durkheim, É. ([1893] 1964). The Division of Labour in Society. NY: Free Press.

[9] Merton, R. K. (1964). Anomie, Anomia, and Social Interaction: Contexts of Deviant Behavior. In M. B. Clinard (Ed.) Anomie and Deviant Behavior: A Discussion and Critique (pp. 213-242). NY: Free Press.

[10] Левина Е., Мартинсоне К., Камераде Д. (2015). Индивидуальная аномия как фактор, прогнозирующий субъективное благополучие. Медииинская психология в России 3 (32), [Электронный pecypc]. URL: http://mprj.ru.

[11] De Man, A.F., Leduc, C.P. (1995). Suicidal ideation in high school students: Depression and other correlates. Journal of Clinical Psychology, 51(2), 173-181.

[12] Heydari, A., Teymoori, A., \& Nasiri, H. (2013-2014). Development of suicidality within socioeconomic context: Mediation effect of parental control and anomie. Omega, 68(1), pp. 63-76. 
[13] Lasky, D.I., Ziegenfuss, J.T. (1979). Anomie and drug use in high school students. The International Journal of the Addiction, 14(6), 861-866.

[14] De Man, A.F., Labrèche-Gauthier, L., \& Leduc, C.P. (1993). Correlates of anomie in French-Canadian adolescents. The Journal of Social Psychology, 133(2), 141-145.

[15] Fromm, E. (1941). Escape from freedom. NY.: Henry Holt and Company.

[16] Horney, K. ([1939] 1947). New ways in psychoanalysis. London: Kegan Paul.

[17] Maslow A. H. (1987). Motivation and personality (3rd ed.) NY.: Harper and Row.

[18] Wilson, J. (2000). Volunteering. Annual Review of Sociology, 26, 215-240.

[19] Wuthnow R. (1991). Acts of compassion: Caring for others and helping ourselves. Princeton, N.J: Princeton University Press.

[20] Durkheim, É. ([1897] 1951). Suicide: A Study in Sociology. London, England: Routledge.

[21] Graeff, P. \& Mehlkop, G. (2007). When anomie becomes a reason for suicide: A new macro-sociological approach in the Durkheimian tradition. European Sociological Review, 23(4), 521-535.

[22] Thorlindsson, T., \& Bjarnason, T. (1998). Modeling Durkheim on the micro level: A study of youth suicidality. American Sociological Review, 63(1), 94-110.

[23] Lantz, J. \& Harper, K. (1990). Anomic depression and the migrating family. Contemporary Family Therapy: An International Journal, 12(2), 153-163.

[24] Levasseur, M., Richard, L., Gauvin, L. \& Raymond, É. (2010). Inventory and analysis of definitions of social participation found in the aging literature: Proposed taxonomy of social activities. Social Science and Medicine, 71(12), 2141-2149. 